\title{
EVALUACIÓN FINANCIERA CON LA METODOLOGÍA DE OPCIONES REALES DE UNA INVERSIÓN PARA PRODUCIR QUITOSANO CON BASE EN DESPERDICIO DE CAMARÓN
}

\section{FINANCIAL EVALUATION WITH THE REAL OPTIONS METHODOLOGY OF AN INVESTMENT TO PRODUCE CHITOSAN BASED ON SHRIMP WASTE}

\author{
Marisol Cadeza-Espinosa ${ }^{1}$, J. de Jesús Brambila-Paz ${ }^{1 *}$, L. Eduardo Chalita-Tovar ${ }^{1}$, Adrián González-Estrada \\ ${ }^{1}$ Colegio de Postgraduados. Carretera Federal México-Texcoco, km 36.5. Montecillo, Texcoco, \\ Estado de México. 56230. (jbrambilaa@colpos.mx). ${ }^{2}$ Instituto Nacional de Investigaciones \\ Forestales, Agrícolas y Pecuarias. Carretera los Reyes-Texcoco, km.13.5. Coatlinchán, Estado \\ de México. 56250.
}

\begin{abstract}
RESUMEN
Las empresas de economías modernas enfrentan el reto de ser rentables y reducir su impacto ecológico. Se está haciendo un esfuerzo científico, tecnológico y económico para sustituir los petroproductos por productos obtenidos de materia prima orgánica. La producción de camarón (Peneus vannamei) genera $400 \mathrm{~kg}$ de desperdicio por tonelada. Ahora ya es viable técnica y económicamente usar ese desperdicio para producir quitosano que sirve de polímero para producir materiales biodegradables. Invertir en un sistema de producción de camarón y de quitosano con desperdicio de camarón es más rentable que mantenerse solamente en la producción. La evaluación financiera del proyecto de camarón-quitosano con la metodología tradicional de Valor Actual Neto (VAN) se tiene que complementar con la metodología de opciones reales que permite considerar en el análisis la volatilidad de los precios del camarón y del quitosano. El resultado es que un proyecto de camarón-quitosano es más rentable $\left(\mathrm{VAN}_{\text {TOTAL }}=\$ 1790\right.$ 000) que si solo se produce camarón (VAN $=\$ 182000)$. Se concluye que es posible aumentar la rentabilidad de la cadena productiva de camarón mediante el tratamiento de su desperdicio para producir quitosano.
\end{abstract}

Palabras clave: biopolímero, desperdicio, impacto ecológico, rentabilidad, volatilidad.

\section{INTRODUCCIÓN}

$\mathrm{L}$ a forma de consumir y producir de las economías modernas no permite darle valor al desperdicio que se genera, y al desecharlo provoca

* Autor responsable * Author for correspondence.

Recibido: septiembre, 2014. Aprobado: octubre, 2016.

Publicado como ARTÍCULO en ASyD 14: 533-545. 2017.

\section{Abstract}

Enterprises in modern economies face the challenge of being profitable and reducing their ecological impact. A scientific, technological and economic effort is being made to substitute petrol products for products obtained from organic raw materials. Shrimp production (Peneus vannamei) generates $400 \mathrm{~kg}$ of waste per ton. Nowadays it is viable technically and economically to use this waste to produce chitosan that serves as a polymer to produce biodegradable materials. Investing in a shrimp and chitosan production system with shrimp waste is more profitable than remaining only in production. The financial evaluation of the shrimp-chitosan project with a traditional methodology of Net Present Value (NPV) must be complemented with the real options methodology that allows considering the volatility of the shrimp and chitosan prices in the analysis. The result is that a shrimp-chitosan project is more profitable $\left(\mathrm{NVP}_{\text {тотАL }}=\$ 1790000\right)$ than if only shrimp is produced $(\mathrm{NVP}=\$ 182000)$. It is concluded that it possible to increase the profitability of the shrimp productive chain through the treatment of its waste to produce chitosan.

Key words: biopolymer, waste, ecological impact, profitability, volatility.

\section{INTRODUCTION}

T The way in which modern economies consume and produce does not allow giving value to the waste that is generated, and when it is disposed it causes problems of pollution and ecological impact. Waste is a residue of what cannot be or isn't easy to use, and wasting is not exploiting something property, although technological advances and the pressure to contaminate less and reduce the 
problemas de contaminación e impacto ecológico. El desperdicio es un residuo de lo que no se puede o no es fácil aprovechar y desperdiciar es no explotar debidamente una cosa, pero el avance tecnológico y la presión por contaminar menos y reducir el impacto ecológico logran que del desperdicio se obtengan productos de alto valor. De hecho, surge una rama nueva de la economía, que es la del desperdicio o la economía circular (DEFRA, 2012; Lacy y Rutquist, 2015).

En el caso de México, en 2013 la captura de camarón de altamar fue $68 \%$ y de acuacultura, $32 \%$ (CONAPESCA, 2014). En el procesamiento y consumo del camarón se genera desperdicio. De Andrade et al. (2012) estiman que de cada tonelada de producción se desperdician $400 \mathrm{~kg}$ y esta materia orgánica se destina a los basureros municipales. Por otro lado, las economías modernas han usado en exceso el petróleo, que es ahora la principal fuente de contaminación y del cambio climatológico. Así, en todas las economías modernas se está haciendo un gran esfuerzo por pasar de la petroeconomía a la bioeconomía, la cual consiste en sustituir los productos de la petroquímica por productos obtenidos de materia orgánica, como son biocombustibles, biomateriales, biopolímeros, etcétera (Brambila, 2011a). Estudios científicos recientes han mostrado que de la cáscara de camarón, que es desperdicio, se puede obtener un biopolímero llamado quitina, chitin en inglés, el cual es insoluble en la mayoría de los disolventes orgánicos, pero a través de un proceso de desacetilación es posible extraer quitosano. De este producto se pueden formar películas de plástico, gomas, geles, hilos, capsulas, entre otros. (Rinaudo, 2006; Pillai et al., 2009; Miranda y Lizárraga, 2012). La quitina es considerada el segundo biopolímero más importante del mundo (Támara et al., 2012; Pradeepa et al., 2014; Lárez, 2006).

El precio del quitosano oscila entre $\$ 700000$ hasta $\$ 8000000$ por tonelada, dependiendo de la pureza y el mercado (Dupont, 2014). Con datos de 2014, el camarón se cotiza en $\$ 44000$ por tonelada en promedio. Este precio varía según el tamaño, la época del año, si es de altamar o de acuacultura, por la región del Pacífico o Golfo, y por estados de la república (INEGI, 2014). Con el desperdicio, el productor de camarón tiene un subproducto de alto valor y con ello la posibilidad de reducir el impacto ecológico. El precio de los productos que sustituyen a los derivados del petróleo es volátil ecological impact manage for high value products to be obtained from the waste. In fact, a new branch of economy arises, which is waste or circular economy (DEFRA, 2012; Lacy and Rutquist, 2015).

In the case of México, in 2013 the shrimp capture in open sea was $68 \%$ and in aquaculture, $32 \%$ (CONAPESCA, 2014). Waste is generated in the processing and consumption of shrimp. De Andrade et al. (2012) estimate that out of each ton of production, $400 \mathrm{~kg}$ are wasted and this organic matter is destined to municipal landfills. On the other hand, modern economies have used petroleum excessively, which is now the main source of pollution and climate change. Thus, in all modern economies a great effort is being made to move from oil-economy to bio-economy, which consists in substituting petrochemical products for products obtained from organic matter, such as biofuels, biomaterials, biopolymers, etc. (Brambila, 2011a). Recent scientific studies have shown that a polymer called chitin can be obtained from shrimp shell, which is a waste; it is insoluble in most organic solvents, although through a process of deacetylation it is possible to extract chitosan. Plastic films, gums, gels, threads, and capsules, among others, can be formed from this product (Rinaudo, 2006; Pillai et al., 2009; Miranda and Lizárraga, 2012). Chitin is considered to be the second most important biopolymer in the world (Támara et al., 2012; Pradeepa et al., 2014; Lárez, 2006).

The price of chitosan ranges between $\$ 700000$ to $\$ 8000000$ per ton, depending on the purity and the market (Dupont, 2014). With data from 2014 , shrimp is listed at $\$ 44000$ per ton in average. This price varies according to the size, the time of the year, whether it is from open sea or aquaculture, from the Pacific or Gulf region, and from states of the republic (INEGI, 2014). With the waste, the shrimp producer has a high-value byproduct and with it the possibility of reducing the ecological impact. The price of the products that substitute petroleum derivatives is volatile because it depends on technological innovation, on the new uses that are found for it and the petroleum price, so that if shrimp enterprises want to take advantage of their waste they must take into account the volatility of shrimp and chitosan prices when making an investment; the latter is correlated with the petroleum price. In order to perform a financial evaluation of a project that 
porque depende de la innovación tecnológica, de los usos nuevos que se le encuentren y del precio del petróleo, así que si las empresas camaroneras quieren aprovechar su desperdicio al llevar a cabo una inversión tienen que tomar en cuenta la volatilidad del precio del camarón y del quitosano; este último se correlaciona con el precio del petróleo. Para hacer una evaluación financiera de un proyecto que participa en un mercado volátil, ya no es suficiente con usar las metodologías tradicionales, como es el del Valor Actual Neto (VAN), el Beneficio-Costo (B/C) y la Tasa Interna de Retorno (TIR), sino que además hay que emplear la metodología de opciones reales (Copeland y Antikarov, 2001; Brach, 2003; Brambila, 2011b).

Opciones reales es una metodología de evaluación financiera que considera que la gerencia de un proyecto toma decisiones a lo largo de la vida útil de este para adecuarse a las circunstancias cambiantes del mercado y la tecnología. La gerencia puede decidir en su momento ampliar, reducir, abandonar, continuar, dejar de ser monovalente para volverse polivalente (Brambila et al., 2013) y entrar a mercados nuevos, como la biotecnología (Álvarez et al., 2012; Vedovoto y Prior, 2015). En el caso específico del camarón (peneus vannamei), la gerencia puede decidir posponer, esperar a conocer qué pasa en el mercado o invertir en una procesadora de desperdicios de camarón para obtener y vender quitosano, teniendo en cuenta la volatilidad de precios de ambos mercados. Valga resaltar que la cantidad de quitosano que se puede producir depende de la cantidad de camarón que se obtenga.

El objetivo de este trabajo es mostrar que una empresa camaronera puede ser rentable si se invierte en un sistema de tratamiento de sus desperdicios para obtener quitosano. Además de ser rentable para la empresa, se reduce el impacto ecológico. La hipótesis del trabajo es que a pesar de la volatilidad de los precios del camarón, del petróleo y, por consiguiente, del quitosano, es más rentable estar en el negocio de camarón-quitosano que solo ser productor de camarón o de quitosano.

\section{Materiales y Métodos}

La evaluación financiera de un proyecto que tiene un producto principal, el camarón en este caso, y el uso de desechos para obtener un subproducto, participates in a volatile market, it is no longer enough to use traditional methodologies, such as Net Present Value (NPV), Benefit-Cost (B/C) and Internal Rate of Return (IRR), but in addition the methodology of real options must be used (Copeland and Antikarov, 2001; Brach, 2003; Brambila, 2011b).

The real options valuation method considers that the management of a project makes decisions throughout its useful life to adapt to changing circumstances of the market and the technology. The management can decide at the time to broaden, reduce, abandon, continue, cease to be monovalent to become polyvalent (Brambila et al., 2013), and to enter new markets, such as biotechnology (Álvarez et al., 2012; Vedovoto and Prior, 2015). In the specific case of shrimp (Peneus vannamei), the management can decide to postpone, wait to know what is happening in the market, or invest in a shrimp waste processor to obtain and sell chitosan, taking into account the price volatility of both markets. It should be highlighted that the amount of chitosan that can be produced depends on the amount of shrimp obtained.

The objective of this study is to show that a shrimp company can be profitable if there is investment in a waste treatment system to obtain chitosan. In addition to being profitable for the enterprise, the ecological impact is reduced. The working hypothesis is that despite the volatility of the shrimp and petroleum prices, and therefore, of chitosan, it is more profitable to be in the shrimp-chitosan business that to be only a shrimp or chitosan producer.

\section{Materials and Methods}

The financial evaluation of a project that has a main product, shrimp in this case, and the use of waste to obtain a byproduct, chitosan, requires understanding the whole shrimp-chitosan system. The shrimp-chitosan process is different from the one just for shrimp or just for chitosan because it allows the recycling of wastes and water. Figure 1 describes the shrimp-chitosan system. The reuse of chitosan is carried out in the seventh link of its productive chain.

Figure 2 exemplifies the shrimp-chitosan system where the shrimp shell is recycled to produce chitosan and water is recycled. In each one of the production systems, organic and inorganic wastes are 


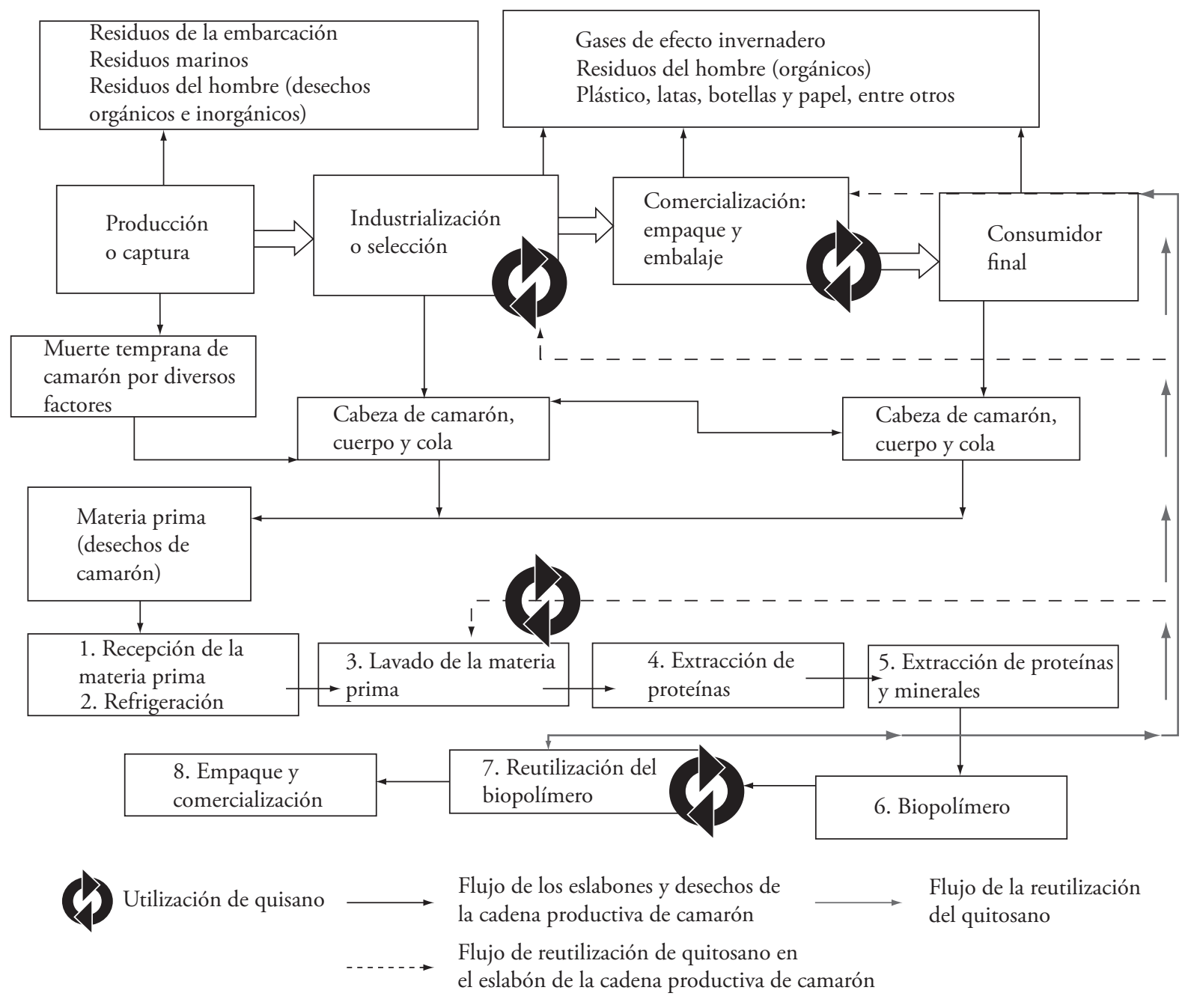

Figura 1. Diagrama de producción de camarón de altamar y quitosano.

Figure 1. Diagram of open sea shrimp production and chitosan.

el quitosano, requiere entender todo el sistema de camarón-quitosano. El proceso camarón-quitosano es diferente al de solo camarón y solo quitosano porque permite el reciclaje de desperdicios y de agua. La Figura 1 describe el sistema camarón-quitosano. La reutilización de quitosano se realiza en el eslabón siete de su cadena productiva.

En la Figura 2 se ejemplifica el sistema camarónquitosano donde se recicla la cáscara de camarón para producir quitosano y se recicla el agua. En cada uno de los sistemas de producción se generan desechos orgánicos e inorgánicos. $\mathrm{Al}$ reciclar el agua se reduce el impacto ambiental. También se aprecia la reutilización de la cáscara de camarón como biomaterial. Con las flechas negras gruesas y más punteadas se señala el eslabón en el sistema camarón-quitosano, en el cual generated. When recycling water, the environmental impact is reduced. The reutilization of shrimp shell as biomaterial is also shown. With the more dotted thick black arrows, the shrimp-chitosan link of the system is shown, where chitosan is reused and water is recycled. In the long term this system will transform into an integral production system where each one of the wastes from the links will become reintegrated into the global productive chain. What is expected is that the production costs will be reduced with this.

The traditional financial evaluation of a project to estimate its Net Present Value (NPV) consists in estimating the benefits and costs in each period and obtaining a cash flow that is updated to the starting period when using a discount rate that was $12 \%$ in this study. The initial investment is subtracted 


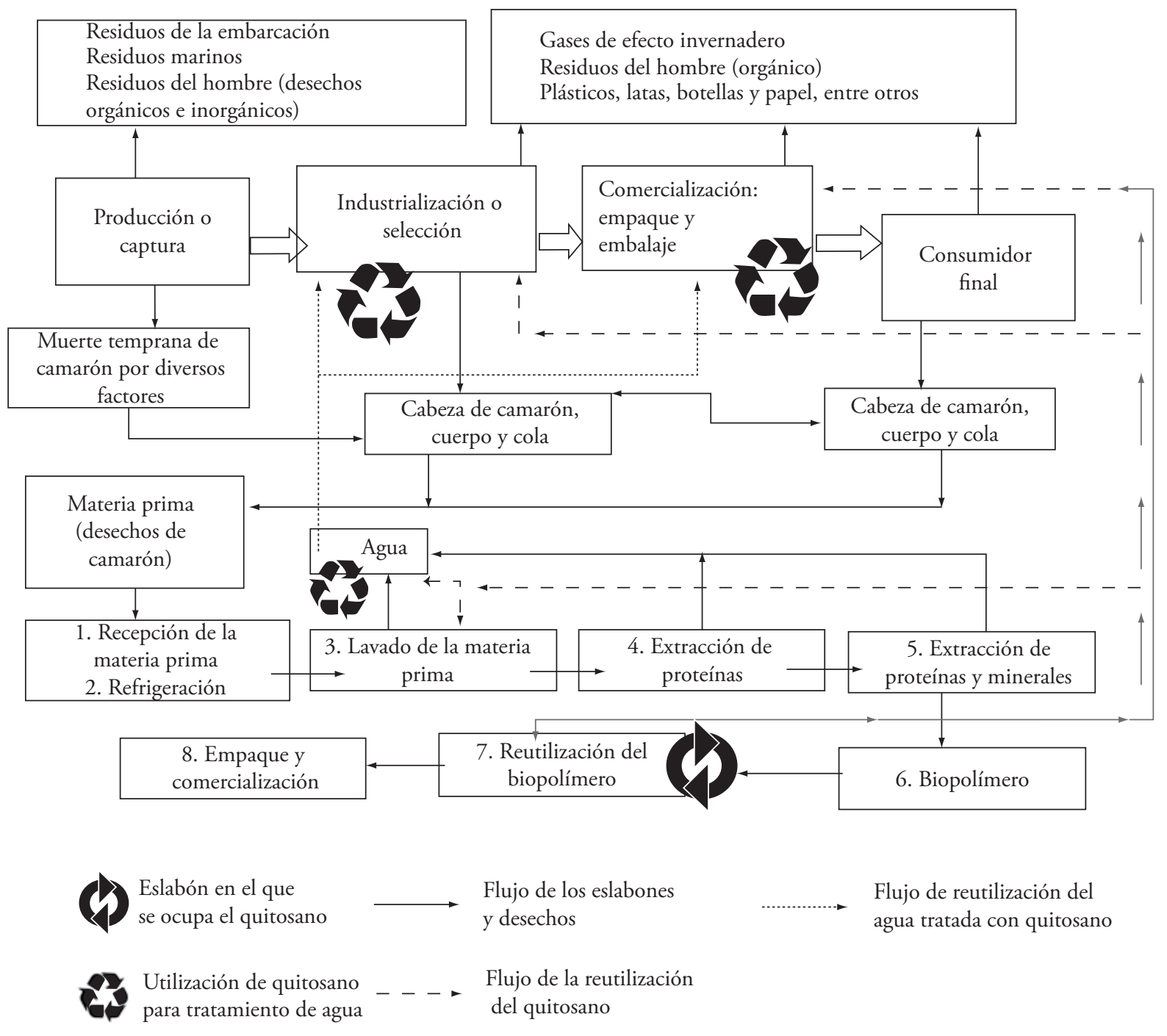

Figura 2. Sistema integral de producción de camarón. Figure 2. Integral shrimp production system.

se reutiliza el quitosano y el reciclaje del agua. En el largo plazo este sistema se transformará en un sistema integral de producción en el que cada uno de los desperdicios de los eslabones se reintegrará a la cadena productiva global. Lo que se espera es que con ello se reduzcan los costos de producción.

La evaluación financiera tradicional de un proyecto para estimar su Valor Actual Neto (VAN) consiste en estimar los beneficios y los costos en cada periodo y obtener un flujo de efectivo que se actualiza al periodo de inicio al usar una tasa de descuento que en este trabajo de investigación fue de $12 \%$. A la suma en valor actual de ese flujo se le resta la inversión inicial y el resultado es el VAN. Si este valor es positivo from the sum in the present value of this flow and the result is the NPV. If this value is positive, it is recommended to invest in the project (Baca, 2010).

$V A N=-I+\frac{\sum_{i=1}^{t}\left(b_{i}-c_{i}\right)}{(1+\partial)^{t}}$

where: $b_{i}$ : Benefit in time $i . c i$ : Cost in time $i$. I: Initial investment. $\partial$ : Discount rate.

The data to calculate the NPV for shrimp were obtained from Trusts Funds for Rural Development (Fideicomisos Instituidos en Relación con la Agricultura, 
se recomienda invertir en el proyecto (Baca, 2010).

$V A N=-I+\frac{\sum_{i=1}^{t}\left(b_{i}-c_{i}\right)}{(1+\partial)^{t}}$

donde: $b$ : Beneficio en el tiempo $i$. $c i$ : Costo en el tiempo $i$. I: Inversión inicial. $\partial$ : Tasa de descuento.

Los datos para hacer el cálculo del VAN para el camarón se obtuvieron de Fideicomisos Instituidos en Relación con la Agricultura (FIRA, 2009) para una embarcación de 16 ton/viaje, con un promedio de seis viajes por temporada. Los precios reales se calcularon con datos del Instituto Nacional de Estadística y Geografía (INEGI, 2014), FIRA (2009) y la Cámara Nacional de Acuacultura y Pesca (CONAPESCA, 2009). Los costos fijos se estimaron en $\$ 639135$ y los variables en $\$ 147276$ por temporada; la inversión inicial se consideró de $\$ 1200000$. El desglose y detalle de los costos se puede revisar en el boletín informativo FIRA (2009).

Los datos para hacer el cálculo del VAN para el quitosano se obtuvieron de Cerón (2010). Se consideró una cantidad de 24 ton y los precios reales se obtuvieron de INEGI (2014) y Shirai (2011). Los costos fijos se estimaron en $\$ 4822683$ y los variables en $\$ 1222$ 683; la inversión inicial que se estimó fue \$2 339 958. El desglose y detalle se pueden revisar en Cerón (2010). La vida útil de los proyectos se consideró de 10 años. Los valores residuales están en el último año y se incluyen para calcular los Valores Actuales Netos respectivos.

La serie estadística del periodo 2000-2011 de precios nominales de camarón de altamar fue tomada del Plan Maestro de camarón de altamar de Sinaloa (CONAPESCA, 2009). Los precios nominales periodo 2000-2011 de quitosano fueron calculados con la información de Shirai (2011) y descontados con el Índice Nacional de Precios al Consumidor (INPC) anual acumulado base 2Q Dic 2010, publicado por el Banco de México (BANXICO, 2014).

Para obtener los precios reales de camarón y quitosano se usó el índice nacional de precios al productor (INPP) base agosto 2014 publicados por INEGI. La fórmula utilizada para la obtención de los precios es:
FIRA, 2009) for a ship of 16 ton/trip, with an average of six trips per season. The real prices were calculated with data from the National Statistics and Geography Institute (Instituto Nacional de Estadística y Geografía, INEGI, 2014), FIRA (2009), and the National Chamber for Aquaculture and Fishing (Cámara Nacional de Acuacultura y Pesca, CONAPESCA, 2009). The fixed costs were estimated at $\$ 639135$ and the variable ones at $\$ 147276$ per season; the initial investment was considered to be $\$ 1200000$. The breakdown and detail of the costs can be reviewed in FIRA's informative bulletin (2009).

The data to carry out the NPV calculation for chitosan were obtained from Cerón (2010). An amount of 24 ton was considered and the real prices were obtained from INEGI (2014) and Shirai (2011). The fixed costs were estimated to be $\$ 4822683$ and the variable ones $\$ 1222683$; the initial investment that was estimated was $\$ 2339958$. The breakdown and detail can be reviewed in Cerón (2010). The useful life of the projects was considered to be 10 years. The residual values are in the last year and are included to calculate the corresponding Net Present Values.

The statistical series of the 2000-2011 period of nominal shrimp prices from open sea was taken from the Master Plan for open sea shrimp from Sinaloa (CONAPESCA, 2009). The nominal chitosan prices for the 2000-2011 period were calculated with information from Shirai (2011) and discounted with the National Consumer Price Index (NCPI) annual accumulated base 2Q Dec 2010, published by the Bank of Mexico (Banco de México, BANXICO, 2014).

To obtain the real prices for shrimp and chitosan, the National Producer Price Index (NPPI) base August 2014 published by INEGI was used. The formula used to obtain the prices is:

$P R=\left(\frac{P N}{I N P P}\right) \times 100$

where: PR: Real Price. PN: Nominal Price. INPP: National Producer Price Index.

Given that the shrimp and chitosan prices are very volatile, the financial evaluation of the shrimpchitosan project must be complemented with the 
$P R=\left(\frac{P N}{I N P P}\right) \times 100$

donde: PR: Precio Real. PN: Precio Nominal. INPP: Índice Nacional de Precios al Productor.

Dado que los precios del camarón y del quitosano son muy volátiles, la evaluación financiera del proyecto camarón-quitosano debe ser complementada con la metodología de opciones reales. Para aplicar la metodología de opciones reales se requiere estimar primero la volatilidad de precios. Esto se hace al calcular la tasa de crecimiento continua (en logaritmos naturales) de los precios de un año a otro.

$$
r_{t}=\ln \left(\frac{P_{t+1}}{P_{t}}\right)
$$

donde $r_{t}$ : tasa continua de crecimiento de los precios reales. $\ln$ : logaritmo natural. $P_{t}$ : precio real en el año t. $P_{t+1}:$ precio real en el ańo $t+1$.

La volatilidad se mide con la desviación estándar de las tasas continuas de los precios reales.

$$
\sqrt{\sigma^{2}}=\sqrt{\frac{\sum_{i=1}^{T}\left(r_{t}-\bar{x}\right)^{2}}{t-1}}=\sigma
$$

donde $\bar{x}$ : promedio de las tasas continuas de cambio. $\sigma$ : desviación estándar de las tasas continuas de los precios reales. t. total de los periodos.

Con el Valor Actual Neto y la desviación estándar de las tasas de cambio continuas de los precios reales se forma el árbol binomial de camarón.

En el caso del sistema camarón-quitosano, la desviación estándar se estimó con los criterios de Markowitz para un portafolio de inversión (Ross et al., 2005).

$$
\Gamma^{2}=X_{1}^{2} \sigma_{1}^{2}+2 X_{1} X_{2} \delta_{12}+X_{2}^{2} \sigma_{2}^{2}
$$

donde $\Gamma^{2}$ : volatilidad del portafolio de camarón y quitosano o varianza de los precios reales de camarón y quitosano. $\sigma_{1}^{2}$ : Volatilidad de los precios reales de camarón o varianza de los precios reales de camarón. $\delta_{12}$ : covarianza entre los precios reales de camarón y real options methodology. To apply the real options valuation method, it is required to estimate first the volatility of prices. This is done when calculating the continuous growth rate (in natural logarithms) of the prices from one year to another.

$r_{t}=\ln \left(\frac{P_{t+1}}{P_{t}}\right)$

where $r_{t}$ : continuous rate of real price growth. $\ln$ : natural logarithm. $P_{t}$ : real price in the year $t . P_{t+1}$ : real price in the year $t+1$.

The volatility is measured with the standard deviation of the continuous rates of real prices.

$$
\sqrt{\sigma^{2}}=\sqrt{\frac{\sum_{i=1}^{T}\left(r_{t}-\bar{x}\right)^{2}}{t-1}}=\sigma
$$

where $\bar{x}$ : average of continuous rates of change. $\sigma$ : standard deviation of the continuous rates of real prices. $t$. total from the periods.

With the Net Present Value and the standard deviation of the continuous change rates of real prices, the binomial tree of shrimp is formed.

In the case of the shrimp-chitosan system, the standard deviation was estimated with the Markowitz criteria for an investment portfolio (Ross et al., 2005).

$\Gamma^{2}=X_{1}^{2} \sigma_{1}^{2}+2 X_{1} X_{2} \delta_{12}+X_{2}^{2} \sigma_{2}^{2}$

where $\Gamma^{2}$ : volatility of the shrimp and chitosan portfolio or variance of real prices of shrimp and chitosan. $\sigma_{1}^{2}$ : Volatility of real prices of shrimp or variance of real prices of shrimp. $\delta_{12}$ : covariance between real prices of shrimp and chitosan. $X_{1}$ : proportion of the total investment destined to the shrimp project. $\sigma_{2}^{2}$ : volatility of the chitosan prices or variance of the real prices of chitosan. $X_{2}$ : proportion of the total investment destined to the chitosan project. The proportions of the amounts of shrimp and chitosan were calculated through the following mathematical relations. $X_{I}$ : initial investment to produce shrimp/ Total investment (shrimp and chitosan). $X_{2}$ : initial investment to produce chitosan / Total investment (shrimp and chitosan). 
quitosano. $X_{1}$ : proporción de la inversión total destinada al proyecto de camarón. $\sigma_{2}^{2}$ : volatilidad de los precios de quitosano o varianza de los precios reales de quitosano. $X_{2}$ : proporción de la inversión total destinada al proyecto de quitosano. Las proporciones de las cantidades de camarón y quitosano se calcularon mediante las siguientes relaciones matemáticas. $X_{I}$ : inversión inicial para producir camarón/ Inversión total (camarón y quitosano). $X_{2}$ : inversión inicial para producir quitosano/ Inversión total (camarón y quitosano).

Para el cálculo de los árboles binomiales con opciones reales se usó la metodología empleada por Copeland y Antikarov (2001), Brach (2003) y Brambila (2011 b), quienes señalan que las opciones reales son el derecho, pero no la obligación de ejercer una acción durante la vida del proyecto. En nuestro caso la opción real que tiene una empresa camaronera es invertir en un proyecto de quitosano y formar un sistema camarón-quitosano con el reciclaje de agua y materia prima ya seńalado. Esto es un derecho, pero no una obligación. Con la desviación estándar $(\sigma)$ se forman los escenarios de la empresa cuando los precios van a la alza $\left(\mathrm{up}=e^{\sigma}\right)$ y cuando los precios van a la baja $\left(\right.$ down $\left.=e^{-\sigma}\right)$, donde $u$ es lo que aumenta el valor del proyecto por incremento en precios, $d$ es lo que baja el valor del proyecto por disminución de precios y $e$ es el número de Euler.

Ya que existe riesgo, el valor del proyecto puede aumentar o disminuir y la probabilidad de que esto ocurra se mide (Brach, 2003; Brambila et al., 2013):

$p=\frac{(1+\ell)-d}{u-d}$

$1-p$

donde $p$ : probabilidad de que aumente el valor del proyecto. $1-p$ : probabilidad de que disminuya el valor del proyecto. $\ell$ : tasa de interés libre de riesgo (promedio de cetes reales).

Se forma un árbol binomial del valor del proyecto al aumentar $(u)$ o disminuir (d) en el tiempo (Figura 3).

Una vez que se tienen todos los nodos y un horizonte para producción de camarón se forma un árbol binomial como la opción real de integrar el sistema
For the calculation of binomial trees with real options, the methodology used by Copeland and Antikarov (2001), Brach (2003) and Brambila (2011b) was used, who point out that the real options are the right, although not the obligation of exercising an action during the project's life. In our case, the real option that a shrimp enterprise has is to invest in a chitosan project and form a shrimpchitosan system with water recycling and the raw material already mentioned. This is a right, but not an obligation. With the standard deviation $(\sigma)$ the scenarios of the enterprise are formed when the prices are rising $\left(\mathrm{up}=e^{\sigma}\right)$ and when the prices are decreasing (down $=e^{-\sigma}$ ), where $u$ is what increases the project's value from a rise in prices, $d$ is what lowers the value of the project from a decrease in prices, and $e$ is the Euler number.

Since there is risk, the project's value can increase or decrease and the probability of this happening is measured (Brach, 2003; Brambila et al., 2013):

$p=\frac{(1+\ell)-d}{u-d}$

$1-p$

where $p$ : probability of an increase in the project's value. $1-p$ : probability of a decrease in the project's value. $\ell$ : risk free interest rate (average of real cetes).

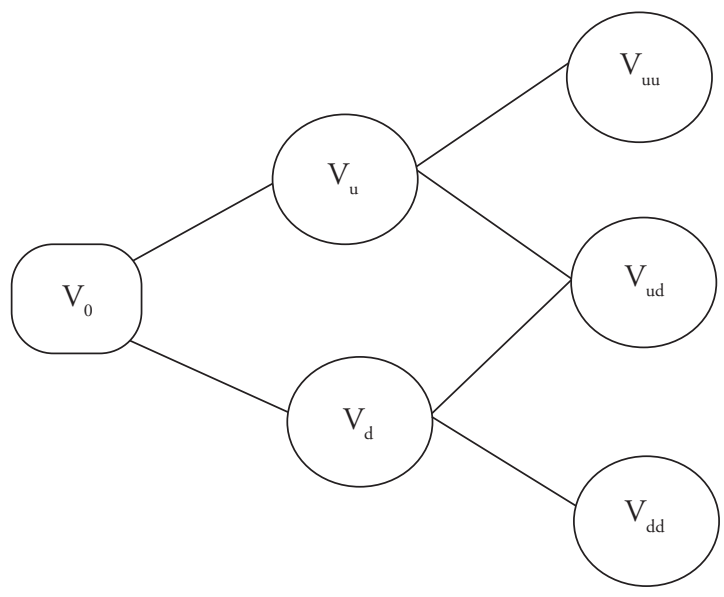

Fuente: Brach (2003) y Brambila et al. (2013). * Source: Brach (2003) and Brambila et al. (2013).

Figura 3. Árbol de decisiones.

Figure 3. Decisions tree. 
camarón-quitosano a partir del segundo año. Para ello, se calcularon los valores en los nodos de atrás para adelante hasta llegar al valor de la opción real de producir camarón-quitosano (Brach, 2003; Brambila et al., 2013).

$V_{Q C}=\frac{p\left(v_{u}\right)+(1-p)\left(v_{d}\right)}{1+\ell}$

donde $V_{Q C}$ Valor Presente Neto en el periodo actual. $p$ : Probabilidad de que aumente el valor del proyecto. $1-p$ : probabilidad de que disminuya el valor del proyecto. $\ell$ : tasa de interés libre de riesgo (promedio de cetes reales). $v_{u}$ : valor presente neto de que aumente el valor del proyecto un periodo anterior. $v_{d}$ valor presente neto de que disminuya el valor del proyecto un periodo anterior.

Mascareñas et al. (2004) y Brambila (2013) indican que el valor actual neto total del proyecto será igual al valor actual neto tradicional más el valor de la opción real de poder optar por la producción de quitosano extraído de la cascara de camarón.

$V A N_{\text {TOTAL }}=V A N+O R$

donde $V A N_{\text {TOTAL }}$ : valor actual neto total. VAN: valor actual neto o valor actual neto tradicional. $O R$ : opción real.

Se estimó la distribución de los valores del proyecto en el último periodo, usando la fórmula de probabilidades binomiales (Copeland y Antikarov, 2001; Brambila et al., 2013).

$$
\begin{aligned}
& B(n / t, p)=\left(\begin{array}{l}
t \\
n
\end{array}\right) p^{n}(1-p)^{t-n}= \\
& \frac{t !}{(t-n) ! n !} p^{n}(1-p)^{t-n}
\end{aligned}
$$

donde $B$ : probabilidad de estar en el nodo $n$ en el momento $t$. $n$ : número de nodos en el periodo $t$. $t$ : periodo evaluado $=1,2 \ldots, 10 . p$ : probabilidad de que aumente el valor del proyecto. $1-p$ : probabilidad de que disminuya el valor del proyecto.

La distribución de los valores de cada periodo se aproxima a una distribución normal, por lo que se
A binomial tree of the value of the project is formed when increasing $(u)$ or decreasing $(d)$ in time (Figure 3).

Once all the nodes and a horizon for shrimp production are found, a binomial tree is formed as the real option of integrating the shrimp-chitosan system starting from the second year. For this purpose, the values in the nodes were calculated backwards until reaching the value of the real option of producing shrimp-chitosan (Brach, 2003; Brambila et al., 2013).

$V_{Q C}=\frac{p\left(v_{u}\right)+(1-p)\left(v_{d}\right)}{1+\ell}$

where $V_{Q C}$ : Net Present Value in the current period. $p$ : Probability of an increase in the project's value. $1-p$ : probability of a decrease in the project's value. $\ell$ : risk free interest rate (average of real cetes). $v_{u}$ : net present value of an increase in the project's value from a previous period. $v_{d}$ : net present value of a decrease in the project's value from a previous period.

Mascareñas et al. (2004) and Brambila (2013) indicate that the total net present value of the project will be equal to the traditional net present value plus the value of the real option of being able to opt for the production of chitosan extracted from shrimp shell.

$V A N_{\text {TOTAL }}=V A N+O R$

where $V A N_{\text {TOTAL }}$ : total net present value. VAN: net present value or traditional net present value. $O R$ : real option.

The distribution of project values in the last period was estimated, using the formula of binomial probabilities (Copeland and Antikarov, 2001; Brambila et al., 2013).

$$
\begin{aligned}
& B(n / t, p)=\left(\begin{array}{l}
t \\
n
\end{array}\right) p^{n}(1-p)^{t-n}= \\
& \frac{t !}{(t-n) ! n !} p^{n}(1-p)^{t-n}
\end{aligned}
$$


pudo estimar la probabilidad de que el proyecto tenga un valor predeterminado, estandarizando los valores y usando las tablas $\mathrm{Z}$ de una distribución normal.

$\frac{x_{i}-\bar{x}}{\sigma}=Z$

donde: $x_{i}$ : valor predeterminado del proyecto. $\bar{x}$ : valor medio del proyecto en el periodo $t$. $\sigma$ : desviación estándar de los valores del proyecto en el periodo $t$.

Se calculan los VAN (tradicional) para el caso del camarón y quitosano como proyectos separados y se construyó sólo el árbol binomial de la producción de camarón. Después se considera que la empresa camaronera ejerce su derecho a integrar el sistema camarón-quitosano en el segundo año y se construyó su árbol binomial.

\section{Resultados y Discusión}

El VAN (metodología tradicional) del proyecto de solo producir camarón fue de $\$ 182000$, por lo que se debe aceptar el proyecto. La tasa de descuento en este proyecto es de $12 \%$; esta considera la tasa bancaria y el riesgo del proyecto (Cuadro 1 y 2). Para el proyecto de quitosano el VAN fue de \$ 1727000 , por lo que también se debe aceptar el proyecto. where $B$ : probability of being in node $n$ in the moment $t$. $n$ : number of nodes in the period $t$. $t$. period evaluated $=1,2 \ldots, 10 . p$ : probability of an increase in the project's value.1- $p$ : probability of a decrease in the project's value.

The distribution of values from each period approaches a normal distribution, so the probability of the project having a predetermined value could be estimated, standardizing the values and using the $\mathrm{Z}$ tables of a normal distribution.

$\frac{x_{i}-\bar{x}}{\sigma}=Z$

where: $x_{i}$ : predetermined value of the project. $x$ : mean value of the project in the period $t . \sigma$ : standard deviation of the project's value in the period $t$.

The NPVs (traditional) are calculated for the case of shrimp and chitosan as separate projects and only the binomial tree of shrimp production was constructed. Then, it is considered that the shrimp enterprise exerts its right to integrate the shrimpchitosan system in the second year and its binomial tree was built.

Cuadro 1. Dinámica del valor del proyecto de producción de camarón (miles de pesos). Table 1. Dynamics of the project value for shrimp production (thousands of pesos).

\begin{tabular}{|c|c|c|c|c|c|c|c|c|c|c|c|}
\hline Valores/Año & $\mathbf{0}$ & 1 & 2 & 3 & 4 & 5 & 6 & 7 & 8 & 9 & 10 \\
\hline & 182 & 198 & 216 & 236 & 257 & 280 & 305 & 332 & 362 & 395 & 430 \\
\hline & & 167 & 182 & 198 & 216 & 236 & 257 & 280 & 305 & 332 & 362 \\
\hline & & & 153 & 167 & 182 & 198 & 216 & 236 & 257 & 280 & 305 \\
\hline & & & & 141 & 153 & 167 & 182 & 198 & 216 & 236 & 257 \\
\hline & & & & & 129 & 141 & 153 & 167 & 182 & 198 & 216 \\
\hline & & & & & & 118 & 129 & 141 & 153 & 167 & 182 \\
\hline & & & & & & & 109 & 118 & 129 & 141 & 153 \\
\hline & & & & & & & & 100 & 109 & 118 & 129 \\
\hline & & & & & & & & & 91 & 100 & 109 \\
\hline & & & & & & & & & & 84 & 91 \\
\hline & & & & & & & & & & & 77 \\
\hline
\end{tabular}

Nota: los indicadores de rentabilidad son $\sigma=0.0861, \mu=1.0899, d=0.9175, p=0.6628,1-p=0.3372$. Note: the profitability indicators are $\sigma=0.0861, \mu=1.0899, d=0.9175, p=0.6628,1-p=0.3372$.

Fuente: Elaboración propia con datos de CONAPESCA (2009) e INEGI (2014). Source: authors' elaboration with data from CONAPESCA (2009) and INEGI (2014). 
Cuadro 2. Dinámica del valor del proyecto producción de camarón con inversión para extracción de quitosano en el segundo ańo (miles de pesos).

Table 2. Dynamics of the project value for shrimp production with investment for the extraction of chitosan in the second year (thousands of pesos).

\begin{tabular}{|c|c|c|c|c|c|c|c|c|c|c|c|}
\hline Valores/Año & 0 & 1 & 2 & 3 & 4 & 5 & 6 & 7 & 8 & 9 & 10 \\
\hline & 1790 & 1864 & 1943 & 4307 & 6070 & 8731 & 12869 & 19435 & 29940 & 46739 & 73452 \\
\hline & & 1834 & 1909 & 2385 & 3255 & 4459 & 6187 & 8780 & 12827 & 19310 & 29789 \\
\hline & & & 1880 & 1366 & 1880 & 2554 & 3441 & 4633 & 6305 & 8794 & 12714 \\
\hline & & & & 749 & 1066 & 1490 & 2046 & 2759 & 3665 & 4833 & 6413 \\
\hline & & & & & 559 & 814 & 1166 & 1638 & 2249 & 3014 & 3943 \\
\hline & & & & & & 403 & 601 & 885 & 1281 & 1813 & 2500 \\
\hline & & & & & & & 280 & 427 & 645 & 962 & 1411 \\
\hline & & & & & & & & 187 & 291 & 449 & 687 \\
\hline & & & & & & & & & 122 & 191 & 299 \\
\hline & & & & & & & & & & 78 & 123 \\
\hline & & & & & & & & & & & 50 \\
\hline
\end{tabular}

Nota: los indicadores de rentabilidad son: $\sigma=0.454, \mu=1.5747, d=0.6351, p=0.4222,1-p=0.5778$. Note: the profitability indicators are: $\sigma=0.454, \mu=1.5747, d=0.6351, p=0.4222,1-p=0.5778$.

Fuente: elaboración propia con datos de FIRA (2009), CONAPESCA (2009), INEGI (2014) y Shirai (2011). Source: authors' elaboration with data from FIRA (2009), CONAPESCA (2009), INEGI (2014) and Shirai (2011).

Ahora si se usa un sistema camarón-quitosano con los reciclajes correspondientes y con opción real en el segundo año de invertir en una procesadora de desperdicio para obtener quitosano, el $V A N_{\text {TOTAL }}$ es de \$ 1790000 (Cuadro 3). Este resultado se confirma en la literatura de opciones reales para otro tipo de proyectos (Fenichel et al., 2008; Támara et al., 2012; Vedovoto et al., 2015). Aún más, se puede dar el caso de que el $V A N$ sea negativo y si se tienen opciones reales el Valor Actual Neto Total se vuelva positivo (Hannevik et al., 2015).

Las probabilidades en cada caso de que el proyecto (camarón y camarón-quitosano) esté en el año 10 por arriba o por debajo de su VAN inicial se contrastan en el Cuadro 3. Asimismo, se reflejan los valores de ganancia por tipo de proyecto. La volatilidad de

\section{Results AND Discussion}

The NPV (traditional methodology) of the project for producing just shrimp was $\$ 182000$, so the project should be accepted. The discount rate in this project is $12 \%$; it takes into account the bank rate and the project's risk (Table 1 and 2). For the chitosan project, the NPV was \$ 1727000 , so the project should be accepted.

Now, if a shrimp-chitosan system is used with the corresponding recycling and with a real option in the second year of investing in a waste processor to obtain chitosan, the $N V P_{\text {TOTAL }}$ is $\$ 1790000$ (Table 3). This result is confirmed in the real options literature for other types of projects (Fenichel et al., 2008; Támara et al., 2012; Vedovoto et al., 2015). Furthermore, the

Cuadro 3. Probabilidades de estar encima o debajo del Valor Actual Neto inicial en el décimo ańo.

Table 3. Probabilities of being above or below the initial Net Present Value in the tenth year.

\begin{tabular}{lccc}
\hline \multicolumn{1}{c}{ Proyecto } & $\begin{array}{c}\text { VAN } \\
\text { (pesos) }\end{array}$ & $\begin{array}{c}\text { Probabilidad } \\
\text { por arriba (\%) }\end{array}$ & $\begin{array}{c}\text { Probabilidad } \\
\text { por debajo (\%) }\end{array}$ \\
\hline Sólo camarón & $\$ 182000$ & 0.6628 & 0.3372 \\
Camarón-quitosano & $\$ 1790000$ & 0.4222 & 0.5778 \\
\hline
\end{tabular}

Fuente: elaboración propia con datos de los Cuadros 1 y 2. * Source: authors' elaboration with data from Tables 1 and 2 . 
los precios del proyecto de camarón $(\sigma=0.0861)$ y la volatilidad de los precios del proyecto de camarónquitosano $(\sigma=0.454)$ se muestran de manera simultánea en las probabilidades utilizadas para el cálculo de cada uno de sus escenarios (árbol binomial).

El valor de la opción real de la decisión de invertir en el segundo año fue \$1 608000 (Cuadro 4). Invertir en un sistema camarón-quitosano es económicamente rentable, técnicamente viable y se reduce el desperdicio y el impacto ecológico.

\section{Conclusiones}

La producción de quitosano a partir de los desechos orgánicos del camarón es económicamente rentable en el largo plazo $\left(O R_{2 A N O}=\$ 1608000\right)$. En la cadena productiva de camarón los desperdicios son una alternativa de generación de ganancias adicionales a las que se obtienen con la producción. La expectativa de los productos de la bioeconomía, tales como biomateriales, biocombustibles, bioplásticos, nutracéuticos, alimentos funcionales, entre otros, obtenidos de materia prima de segunda generación o de los residuos sólidos se convierte en una opción atractiva de generar ingresos. Entonces, la utilización de la cáscara de camarón para la extracción de un biopolímero con alto valor en el mercado químico-industrial se convierte en una opción rentable en la producción de camarón. Se concluye que la producción de quitosano a partir de los desechos de la cáscara de camarón es económicamente rentable y de menor impacto ecológico (menos desperdicio), esto a pesar de la volatilidad de los precios del camarón, del petróleo.

\section{Literatura Citada}

Álvarez Echeverría, Francisco Antonio, Pablo López Sarabia, y Francisco Venegas Martínez. 2012. Valuación financiera de proyectos de inversión en nuevas tecnologías con opciones reales. Contaduría y Administración. Vol. 57, Núm. 3, julioseptiembre.

Baca, Urbina Gabriel. 2010. Evaluación de proyectos. Sexta Edición. McGrawHill. México. 181-184 p.

BANXICO (Banco de México). Estadísticas. Índice Nacional de Precios al consumidor acumulado. http: //www.banxico.org. mx. Página consultada 1 de Marzo de 2014.

Brambila Paz, José de Jesús. 2011a. Bioeconomía: Conceptos y Fundamentos, México, SAGARPA-COLPOS. 334 p.

Brambila Paz, José de Jesús. 2011b. Bioeconomía: Instrumentos
Cuadro 4. Comparativo de ganancias por actividad productiva.

Table 4. Comparison of earnings per productive activity.

\begin{tabular}{lcc}
\hline $\begin{array}{c}\text { Concepto/Tipo de } \\
\text { actividad productiva }\end{array}$ & $\begin{array}{c}\text { Captura de } \\
\text { camarón } \\
\text { (pesos) }\end{array}$ & $\begin{array}{c}\text { Empresa camaronera } \\
\text { que invierte para extraer } \\
\text { quitosano en el segundo } \\
\text { año (pesos) }\end{array}$ \\
\hline VAN & $\$ 182000$ & $\$ 1790000$ \\
OR & $\$ 1608000$ & \\
VAN $_{\text {TOTAL }}$ & $\$ 1790000$ & \\
\hline
\end{tabular}

Fuente: elaboración propia con datos de árboles binomiales. * Source: authors' elaboration with data from binomial trees.

case may be that the NPV will be negative and if there are real options the Total Net Present Value can become positive (Hannevik et al., 2015).

The probabilities in each case for the project (shrimp and shrimp-chitosan) to be in the year 10 above or below its initial NPV are contrasted in Table 3. Likewise, the earning values per type of project are reflected. The volatility of the prices of the shrimp project $(\sigma=0.0861)$ and the volatility of the prices of the shrimp-chitosan project $(\sigma=0.454)$ are shown simultaneously in the probabilities used for the calculation of each one of the scenarios (binomial tree).

The value of the real option of the decision to invest in the second year was $\$ 1608000$ (Table 4). Investing in a shrimp-chitosan system is economically profitable, technically viable, and the waste and ecological impact are reduced.

\section{Conclusions}

Chitosan production from organic shrimp waste is economically profitable in the long term $\left(O R_{\text {YYEAR }}=\$ 1608000\right)$. In the shrimp productive chain, wastes are an alternative for the generation of earnings additional to the ones obtained with the production. The expectation of products from bioeconomy, such as biomaterials, biofuels, bioplastics, nutraceuticals, and functional foods, among others, obtained from second generation raw material or from solid residues becomes an attractive option for income generation. Therefore, the use of shrimp shell for the extraction of a polymer of high value in the chemical-industrial market becomes a profitable option in shrimp production. It is 
para su Análisis Económico. México, SAGARPA-COLPOS. $312 \mathrm{p}$.

Brambila Paz, José de Jesús, Miguel Ángel Martínez Damián, María Magdalena Rojas Rojas, y Verónica Pérez Cerecedo. 2013. La bioeconomía, las biorefinerías y las opciones reales: el caso del bioetanol y el azúcar. Agrociencia. Vol. 27, Núm 3, Abril.

Brach, Marion. 2003. Real Options in Practice. John Willey and Sons. New York. 384 p.

Cerón, Emilio, Jorge Echeverría, y Karen Torres. 2010. Propuesta de automatización y control para un proceso de obtención de un polímero biodegradable llamado quitosano. México, IPN. 124p.

CONAPESCA (Comisión Nacional de Acuacultura y Pesca). 2014. Estadística pesquera y acuícola de México. http:// www.conapesca.gob.mx/. Página consultada: 26 de septiembre.

CONAPESCA (Comisión Nacional de Acuacultura y Pesca). 2009. Instituto Sinaloense de Acuacultura (ISA), Comité Sistema Producto Camarón de Altamar de Sinaloa. Plan Maestro de camarón de altamar del estado de Sinaloa. México, CONAPESCA.

Copeland, Thomas, y Vladimir Antikarov. 2001. Real Option: a Practitioner's Guide, New York, Texere. 215 p.

De Andrade Sânia, MB, Rasiah Ladchumananandasivam, Brismak G da Rocha, Débora D Belarmino, y Alcione O Galvão. 2012. The Use of Exoskeletons of Shrimp (Litopenaeus vanammei) and Crab (Ucides cordatus) for the Extraction of Chitosan and Production of Nanomembrane. Materials Sciences and Applicationol. Vol 3. num. 7, july 2012.

DEFRA (Departament of Environment, Food and Rural Affairs). 2012. The economics of waste and waste policy. Reino Unido. $42 \mathrm{p}$.

Dupont. 2014. Plásticos, polímeros y resinas. http://www.dupont.mx/. Página consultada: 5 de Junio de 2014.

Fenichel, Eli, Jean Itasao, Michael Jones, y Graham J. Hickling. 2008. Real options for precautory fisheries management. Fish and Fisheries. Vol. 9.

FIRA (Fideicomisos Instituidos en Relación a la Agricultura). 2009. Situación actual y perspectivas del camarón en México. Núm 3, Año 2009. http://www.fira.gob.mx/. Página consultada: 10 de septiembre de 2014.

Hannevik, Jorgen, Magnus Naustdal, y Henrik Struksnaes. 2015. Real options valuation under technological uncertainty: A case study of investment in post-smolt facility. Noruega, Norwegian University of Science and Technology. 125 p.

INEGI (Instituto Nacional de Estadística, Geografía e Informática). 2014. Índice Nacional de Precios al Consumidor 2Q agosto 2014. http://www.inegi.org.mx/. Página consultada: concluded that chitosan production from shrimp shell wastes is economically profitable and of less ecological impact (less waste); this, despite the volatility of the shrimp and petroleum prices.

$$
\text { - End of the English version - }
$$

17 de septiembre de 2014.

Lacy, Peter, y Jakob Rutquist. 2015. Waste to Wealth: The circular Economy Advantage, New York, Palgrave Macmillan. $266 \mathrm{p}$.

Lárez Velásquez, Cristóbal. 2006. Quitina y quitosano: materiales del pasado para el presente y el futuro. Avances en Química. Vol. 1, Núm. 2.

Mascareñas, Juan Manuel, Prosper Lamothe Fernández, Francisco J. López Lubián, y Walter de Luna Butz. 2004. Opciones Reales y Valoración de Activos: Como medir la Flexibilidad Operativa en la Empresa. Madrid, Pearson Educación. 238 p.

Miranda Castro, Patricia, y Eva Guadalupe Lizárraga Paulín. 2012. Is Chitosan a New Panacea?. Areas of Application. In: Desiree Nedra Karunaratne (coord). The Complex World of Polysaccharides. India. InTech. pp: 1-44.

Pillai, CKS, Paul Willi, and Sharma Chandra. 2009. Chitin and Chitosan polymers: Chemistry, solubility and fiber formation. Progress in Polymer Science. Vol. 34.

Pradeepa, GC, Yun Hee Choia, Yoon Seok Choia, Se Eun Suha, Jeong Heon Seonga, Seung Sik Chob, Min-Suk Baec, and Jin Cheol Yooa. 2014. An extremely alkaline novel chitinase from Streptomyces sp. CS495. Process Biochemistry. Vol. 49, Núm. 2.

Rinaudo, Marguerite. 2006. Chitin and Chitosan: properties and applications. Progress in Polymer Science. Vol. 31.

Ross, Stephen, Randolph Westerfield, and Jeffrey Jaffe. 2005. Corporate finance. McGrawHill. Boston. Sexta edición. 243 p.

Shirai Matsumoto, Keiko. 2011. Producción de quitina y quitosano: nuevo proceso biotecnológico para la obtención de quitina y quitosano. México, Universidad Autónoma Metropolitana. $40 \mathrm{p}$.

Támara Ayús, Armando Lenin, y Raúl Enrique Aristizábal Velásquez. 2012. Las opciones reales como metodología alternativa en la evaluación de proyectos de inversión. Ecos de economía. Vol. 16, Núm. 35, julio-diciembre 2012.

Vedovoto, Graciela Luzia, y Diego Prior. 2015. Opciones reales: una propuesta para valorar proyectos $\mathrm{I}+\mathrm{D}$ en centros públicos de investigación agraria. Contaduría y Administración. Vol. 60, Núm. 1, enero-marzo, 2015. 